\title{
An Analytical Review of Islamic and International Laws on Civilian Right to Life and Human Dignity
}

\author{
Magaji Chiroma "Umar A. Oseni ${ }^{* *}$,Goni Usman Ansari ${ }^{* * *}$ \\ A PhD Researcher at Ahmad Ibrahim Kulliyyah of Laws, IIUM Malaysia and a Lecturer Faculty of Law \\ University of Maiduguri, Nigeria \\ Asst. Proffessor at Ahmad Ibrahim Kulliyyah of Laws, IIUM Malaysia \\ A PhD researcher at Faculty of law University of Maiduguri and a Lecturer at Faculty of Law University of \\ Maiduguri, Nigeria
}

\begin{abstract}
Right to life and Human dignity are among the cardinals of fundamental human rights provided for by the major legal systems in the world. Thus, unnecessarily taking of human soul and inhumane and degrading treatment is totally condemned by the world major legal systems. Feasible measures should always be taken by the parties to a conflict in order to avoid loss of civilian lives and injury to their persons. Any indiscriminate attack against civilians would certainly amount to a violation of their fundamental human rights. However, civilians forfeit their fundamental human rights (particularly rights to life and human dignity) if for instance they violate the rules governing the conduct of hostilities or by simply participating in the hostilities. Participation of civilian in hostilities is indeed one of the factors that can always blur the dividing line between an actual civilian and a combatant. But the extent of the participation according to Islamic and International laws is always controversial. It is therefore against this backdrop that the paper reviews and analyzes the Islamic and International laws relating to civilian rights to life and human dignity.
\end{abstract}

Keywords: Civilian, International Law, Islamic Law, Right to Life \& Human Dignity

\section{Introduction}

Nowadays, violent attacks against civilians and subsequent justifications or denials that usually follow back by government officials, security agents, individuals and militant groups, have no doubt raises a lot of questions unanswered. Such violations of civilian human rights (particularly right to life and human dignity) were seen to be devastated in many conflicts around the globe most especially within the Muslim dominated states. Mostly, the attacks have been attributed to so many factors depending on circumstances surrounding each situation. People do accuses both security agents and militants for infringing over the civilian rights during hostilities. However, the security agents in most cases denying or sometimes justifying the attacks based on the ground that civilians do participate in hostilities. It is certain that once a civilian participate in hostilities or violate the rules of conduct of hostilities ceases to be a civilian and therefore could not be accorded with a civilian status. But the most complicated and fundamental issue that has always been generating a series of debates is the extent of participation to which civilians are said to have been forfeited their civilian status. Of course, this is one of the fundamental issues to be examined in this paper.

Similarly, it is also paramount for the purpose of civilian protection, to examine the efficacy of some of the existing laws governing protection of civilian right to life and human dignity during conflicts. In doing that, a cursory look at the Northern Nigerian (Boko Haram) crises would be made. The paper reviews and analyses the Islamic and International laws relating to civilian rights to life and human dignity during conflicts. This can equally pave a way for examining the extent to which a civilian could forfeit his civilian status under Islamic and International laws. Finally, the paper ends with conclusion and recommendations.

\subsection{Islamic Law}

\section{Definitions of the Key Terms}

Generally, the term Islamic law is used interchangeably with Shari'a ' which is an Arabic word literally means path to a pious. ${ }^{1}$ Technically, it is the Muslim approach and Islamic compliant life which does not solely limited to legal matters. ${ }^{2}$ Similarly, according to Doi, ${ }^{3}$ Shari' $a$ is an Arabic word which literally means the way

\footnotetext{
${ }^{1}$ N. Badawi, Introduction to Islamic law, Programme on Humanitarian Policy and Conflict Research (USA, Harvard University, 2009) 2 see also M. Kyari, 'Application of Shari’a in Borno under the Colonial Rule, (1902-1960),' in M. A. Muazu et al (eds), Perspective in Sharia (Maiduguri, Nigeria, Sakirabe Publishers 2002) 188

${ }^{2}$ Ibid
} 
to a watering place or the path to be followed. ${ }^{4}$ However, in the Qur'an, it has been described as the path not only leading to Allah the Most High, but the path believed by all Muslims to be the path shown by Allah, the Creator Himself through his Messenger Prophet Muhammad (PBUH). ${ }^{5}$ But specifically, the term Islamic International law according to Saheen and Javaid ${ }^{6}$ could be defined as "Siyar": a branch of Islamic law which has been recognized as an integral part of Islamic jurisprudence. ${ }^{7}$ The term Siyar according to Khadduri ${ }^{8}$ is the Islamic law of nations which stands as a chapter in the Islamic corpus juries, binding upon all who believed in it and as well as upon those who sought to protect their interests in accordance with Islamic Justice. ${ }^{9}$ Similarly, in the words of Hamidullah, ${ }^{10}$ Siyar has been conceived as that part of the law and custom of the land and treaty obligations which a Muslim de facto or de jure state observes in its dealings with other de facto or de jure states. ${ }^{11}$ In a nutshell, according to $\mathrm{Al}$ Ghunaimi, ${ }^{12}$ Islamic International law can be loosely defined as those rules and practices the shari'a allows in International relations. ${ }^{13}$

\subsection{International Law}

International law can be defined as the rules and principles that govern states in their relation inter se. ${ }^{14}$ This means that the law mostly concern about states in cooperate entity, and that is why some times it is called "the law of nations". ${ }^{15}$ According to the Soviet Academy of Sciences, International law is "the aggregate of rules governing relations between states in the process of their conflict and cooperation, designed to safeguard their peaceful co-existence, expressing the will of the ruling classes of these states and defended in case of need by coercion applied by states individually or collectively". ${ }^{16}$ Similarly, Denning, L.J in the case of Trendtex Trading Corp V. Central Bank of Nigeria" ${ }^{17}$ was quoted to have said thus: "what then is International law? I know no better definition of it than it is the sum of rules or usages which civilized states have agreed shall be binding upon them in their dealings with one another..."18 However, according to Naqib, ${ }^{19}$ the above definitions, though are corrects but traditional in nature and therefore do not reflect the reality of modern times. ${ }^{20} \mathrm{He}$ said, the definition of "civilized states" in recent time is more generic than what it was before where only Europe was regarded as a civilized state. ${ }^{21}$ More so, many developments have been recorded nowadays with the existence of International organizations and non governmental organizations (which are not states per se) but are established by states and private Individuals. In view of the development, some scholars like Williams and $\mathrm{ALC}^{22}$ have redefined International law as "the system of law containing principles, customs standards and rules by which relations between states and other International persons are governed.",23

\subsection{Civilian}

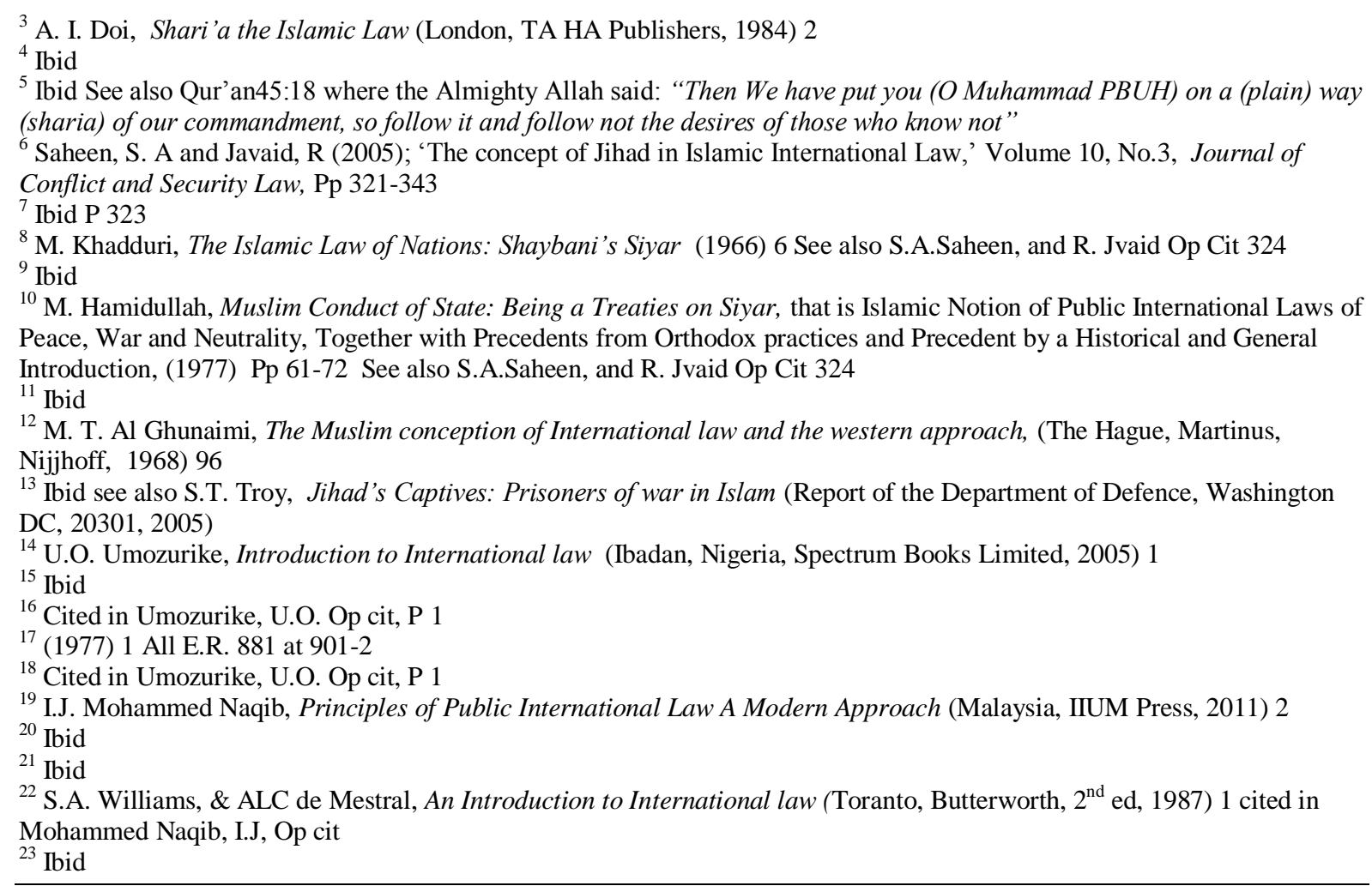


Under Islamic law, there is no tentative definition of the term "civilian". However, analogy has been drawn from the meaning of combatants who carries arms against Muslims and has the physical and mental ability to engage in a war, and does wage war directly or indirectly against Muslims. ${ }^{24}$ That is to say, noncombatants who do not participate in hostilities are regarded under Islamic law as civilians. ${ }^{25}$ Although, there are some controversies still in Islamic scholarship as to who is actually a combatant but that does not negate the previous analogy. Thus, Yamani argued that, any able-bodied man is a combatant, whether or not he is actually a participant in the hostilities. ${ }^{26}$ This implies that unable person who by his nature cannot actively participate in the hostilities such as elderly person; children and women are regarded as "civilians". Other scholars like Shafi'i argued that elderly and monks, who would have been ordinarily protected, may be killed if they have indirectly involved in hostilities. This is because, in a tradition of the Prophet (PBUH), it was reported that a one hundred and fifty year old man was killed in the battle of Hunayn (Fought 8 A.H./ 630 A.D, after the conquest of Mecca) but then the Prophet (PBUH) did not condemn it, this was due to the fact that the old man was alleged to have provided helpful advice to enemies during the battle. ${ }^{27}$

Similarly, under the International law (International humanitarian law), a civilian is defined as any person not belonging to the armed forces ${ }^{28}$ or whose status is in doubt for being a civilian. ${ }^{29}$ Thus, any person who is not a member of his or her county's armed forces or other militia or militant organization is a civilian. ${ }^{30}$ This means that the term is also used to refer to people who are not members of a particular profession or occupation, especially the law enforcement agencies, which often use rank structures similar to those of military units. $^{31}$ According to Sassoli and Bourvia, ${ }^{32}$ it is logical that Article 50(1) of the Additional Protocol 1 of 1977 to the Geneva Convention defines civilian by exclusion from the complementary category of combatants. Everyone who is not a combatant or a civilian while unlawfully directly participating in hostilities is a civilian benefiting from the protection provided for by the law on the conduct of hostilities. Meanwhile, according to Doswald-Beck, ${ }^{33}$ before attaining a civilian status, civilian does not carry arms or is not identifiable by Insignias or military signs such as the military uniform. ${ }^{34}$ However, the presence of individuals other than civilian persons within the civilian population does not deprive the population of its civilian character. ${ }^{35}$ Therefore, the amalgamation of articles 4 and 50 of the Geneva Conventions and its Additional Protocol 1gives a comprehensive definition of a civilian under International armed conflict. ${ }^{36}$

More importantly, a demarcation has been drawn for the purpose of the principle of distinction as to who is a civilian under International and non-International armed conflicts. Thus in International armed conflicts, civilians are defined as all persons who are neither members of the armed forces of a party to the conflict nor

\footnotetext{
${ }^{24}$ See also M. M. Mahboub, War and the Protection of Rights of Individuals: An Examination of Islamic and International Humanitarian Laws (Triumph Publishing Company, (nd)19

${ }^{25}$ K. Bennoune, ‘Assalamu Alaikum? Humanitarian Law in Islamic Jurisprudence,' (Vol. 15, No.2) Michigan Journal of International Law (MICH. J. INT’'L.)1994, 628-629

${ }^{26}$ N. Badawi, Islamic Jurisprudence and the Regulation of Armed Conflict, Programme on Humanitarian Policy and Conflict Research, (USA, Harvard University, 2009) 10. Also available at http://ihl.ihlresearch.org/_data/global/images/Islamic_Jurisprudence_Regulation_AC.pdf (accessed on the November, 26 ${ }^{\text {th }}$ 2010). See also K. Bennoune, Op cit, Pp 628 - 629.

${ }^{27}$ N. Badawi, Op cit

${ }^{28}$ Because any member of armed forces is a combatant by virtue of Article 4 of the Geneva Convention 1949 which provides that: "any member of the armed forces of a party to a conflict is a combatant."

${ }^{29}$ ICRC, Basic Rules of the Geneva Conventions and their Additional Protocols, (Geneva, ICRC, 2006).36

Article 50 of the Additional Protocol 1 of 1977 to the Geneva Convention, which states that civilian person is any person who does not belong to the armed forces and does not take part in levee en masse. In case of doubt, whether a person is a civilian or not, that person shall be considered as a civilian.

${ }^{30}$ Available at http://www.answers.com/topic/civilian, accessed on the November, $1^{\text {st }} 2010$

${ }^{31}$ Ibid

${ }^{32}$ M. Sassoli, and A. A. Bourvia, How Does Law Protects in War (Cases Documents and Teaching Materials on Contemporary Practice), International Humanitarian Law (Geneva, ICRC, 1999). 163. See also Article 51(3) of the Additional Protocol 11977 to the Geneva Convention.

${ }^{33}$ L. Doswald-Beck (et al), International Humanitarian Law, An Anthology (Lexis Nexis- Butterworhs Wadhwa, India 2009) 127

${ }^{34}$ Ibid

${ }^{35}$ ICRC, Hand Book on the Law of War for Armed Forces (ICRC, Geneva, 1999) P. 13

${ }^{36}$ Article 50 of the Additional Protocol 1 of 1977 to the Geneva Convention, states that civilian person is any person who does not belong to the armed forces and does not take part in levee en masse. In case of doubt, whether a person is a civilian or not, that person shall be considered as a civilian. Whereas, Article 4 of the Geneva Convention 1949 provides that: "any member of the armed forces of a party to the conflict is a combatant." This implies that, a civilian is any person who is not a combatant, since a member of armed forces of a party to the conflict has been defined as "combatant".
} 
participants in a levee en masse, ${ }^{37}$ whereas, in non International armed conflicts even though neither Article 3 common to the Geneva Conventions nor provisions of the Additional Protocol II to the Geneva Conventions ${ }^{38}$ has explicitly provided for the definition of civilian, but it has been agreed that any person other than organized groups is civilian, because, organized groups constitute the armed forces of a non-state party to the conflict and consist only of individuals whose continuous function is to take a direct part in hostilities (continuous combat function). ${ }^{39}$ The effort made by various scholars in attempting to define civilian under non international armed conflict as: "any person other than organized armed groups" has been perceived as a deficient definition. This is because; there was no yardstick or criterion of arriving at a conclusion that says "organized armed groups" constitute armed forces of non-state party. It is also not certain specifically as to what point in time the "organized armed groups" would be recognized as a formed regular armed units so that they could be presumed of having knowledge and respect of the laws and customs of war which will consequently qualify them as members of armed forces.

\subsection{Right to Life and Human Dignity}

Right to life is a right accorded to human beings by the International and regional Instruments in order to protect and safeguard the human race in the world. ${ }^{40}$ Thus, no one shall be deprived intentionally of that right, save in execution of the sentence of a court in respect of criminal offence of which he has been found guilty. ${ }^{41}$ Similarly, under Islamic law, it is a right given to the entire mankind irrespective of their sex, race, religion and geographical location. ${ }^{42}$ Human dignity on the other hand connotes inviolability of the human person, recognition of a set of rights and obligations and guarantee of safe conduct by others, including the society and state. ${ }^{43}$ In Classical Roman definition, human dignity is referred to as "dignitas hominis" meaning "status. ${ }^{.44}$ That is to say honour and respect should be accorded to someone who was worthy of that honour and respect because of a particular status that he or she had. ${ }^{45}$ In the Nigerian constitution, human dignity has been associated with three different features, namely: human treatment, freedom and free will (consent). ${ }^{46}$ That is to say, every individual is entitled to respect for the dignity of his person, and accordingly, shall not be subjected to torture or to inhuman or degrading treatment; or be held in slavery or servitude; or be required to perform forced or compulsory labour as they are all considered as violations of human dignity. ${ }^{47}$

\section{A Cursory Insight into the Situation in Northern Nigeria}

Since July, $26^{\text {th }} 2009$ when the Boko Haram (better known as Jama'atu ahlus-sunnah lid-da'awati wal Jihad) crises started in the Northern part of Nigeria, many civilians are reported to have been killed either by the militant group or the state security agents. ${ }^{48}$ According to a repor ${ }^{49}$ which lamented about the arbitrary or unlawful deprivation of life by the government' agencies said that the JTF had used excessive force during raids on militant groups and suspects in Borno state which resulted in deaths, injuries, mass rape, displacement of civilians and other abuses. ${ }^{50}$ Similarly, Oransanye and Igbafe ${ }^{51}$ said that about a thousand persons are said to lose their lives annually in bloody encounters between militia, communities and law enforcement forces in Northern Nigeria. ${ }^{52}$ In fact, the recent report issued by the Amnesty International has revealed that civilians in

\footnotetext{
${ }^{37}$ Levee en Masse refers to the inhabitants of a non-occupied territory who on the approach of the enemy, spontaneously take up arms to resist the invading forces without having had time to form themselves into regular armed units, provided they carry out openly and respect the laws and customs of war.

${ }^{38}$ These are instruments under International Humanitarian law which are applicable during Non International armed conflict

${ }^{39}$ ICRC, 'Interpretative Guidance on the Notion of Direct Participation in Hostilities under the International Humanitarian Law,' ICRC, (2009), Pp. 20-27

${ }^{40}$ M. Nowak, J. Klok and I. Schwarz (et al), Human Rights: Hand Book for Parliamentarian, No:8, 2005) 1

${ }^{41}$ Section 33 of the Constitution of the Federal Republic of Nigeria 1999 (as amended)

${ }^{42}$ Syed Abu A'la Maududi, Human Rights in Islam, (13-E Shah Alam Market, Lahore, Pakistan Islamic Publication Limited) 13-14

${ }^{43}$ M. H. Kamali, Human dignity in Islam (Malaysia, International Institute of Advanced Islamic studies IAIS, 2008)1

${ }^{44}$ M. Christopher, 'Human dignity and judicial Interpretation of Human rights,' European Journal of International law, Vol.19, No.4,P 657

${ }^{45}$ Ibid

${ }^{46}$ Section 34 (1) (a-c) of the Constitution of the Federal Republic of Nigeria 1999 (as amended)

${ }^{47}$ Ibid

${ }^{48}$ O. Bamidele, 'Boko Haram Catastrophic Terrorism- An Albatros to National Peace Security and Sustainable Development in Nigeria' Journal of Sustainable Development in Africa, Vol. 14, No. 1, 35

${ }^{49}$ US report available at http://elombah.com/us/report, accessed on the July, $15^{\text {th }}$ 2012, P 2

${ }^{50} \mathrm{Ibid}, \mathrm{P} 8$

${ }^{51}$ A. O. Oransanye, and A. A. Igbafe, An Assessment of the Terrain of Conflicts, Violence and Crimes, , African Journal of Social Sciences, Vol. 2, No 1 2012, 12

${ }^{52} \mathrm{Ibid}$
} 
Nigeria are in lose - lose situation. ${ }^{53}$ That is to say, the civilians are in dilemma, whenever they turn to their right, there is a militant group who poses threat to their lives, whereas on their left also is the security agents who have been using excessive force to their detriment, both sides are deadly. ${ }^{54}$ This has indeed generated a serious problem which has claimed the lives scores of about more than 800 persons were death and 4000 displaced, just in $2009 .{ }^{55}$ However, this statistics was too low and incomparable with the total estimate for the extra judicial killings committed between the year 1996-2008 alone, where it was revealed that over 128 innocent people were reported to have been killed in the country. ${ }^{56}$ In fact the situation is becoming worse day in day out ${ }^{57}$ and no necessary measures are taken to prevent the civilian casualties by all the concern parties. Both the militants and the security agents have an obligation to ensure respect for the peoples' human rights especially those who do not participate in the hostilities. ${ }^{58}$ But then, they remain the prime suspects for the perpetration of those serious human rights violations of hundreds of people in Northern Nigeria.

The questions now are: What is the government doing about it? Where is the law and where exactly the problem lies? Certainly, answers to these types of questions are always controversial. It is a notorious principle under the International law that human rights law applies at all times (both in armed conflict and in peace) while International humanitarian law applies only during armed conflicts. This implies that no application and as well as the implementation of International humanitarian law could be made in internal conflicts such as riots, civil disturbance or tension. Similarly, human rights law can only be implemented or enforced by governments, whereas; it is the responsibility of everybody to implement the humanitarian law which can apply only during armed conflicts. However, this has indeed created a relative gap in a situation like that of Northern Nigeria where the conflict has not yet reached to a level of armed conflict. Thus, the International humanitarian law does not apply there, and the government is reluctant to effectively enforce the human right law through its agencies. More so, the Islamic law which is the most recognized law by the majority of the Northern people has not been put into full practice.

\section{An Analytical Review of the Civilian Rights to Life and Human Dignity under Islamic Law}

Generally, the concept of human right in Islam has originated from the Glorious Qur'an and Sunnah of the Prophet (PBUH). Thus, the Almighty Allah has granted such rights to all mankind in order to protect and preserve the dignity of their human nature. ${ }^{59}$ Specifically, He (Allah) has made the lives and dignity of human beings as the most sacred and famous among all that need to be preserved. To this end, Abu A'la Al Maududi ${ }^{60}$ says that human soul has been made sacred and could not be tempered with except through the due process of law. ${ }^{61}$ He made reference to the Glorious Qur'an where the Almighty Allah equates a killing of a single soul with a killing of the entire mankind. Thus: "Whosoever kills a human being without (any reason like) manslaughter or corruption on earth, it is as though he had killed all mankind..." ${ }^{\circ 2}$ Similarly, in a Hadith of the Prophet (PBUH) where he was reported to have said:

"Truly, your blood, honour, and your wealth are unlawful to one another. They are unlawful to temper with, like it is unlawful to temper with this (honourable sacred) day (the day of Arafah during Hajj), in this sacred month (the month of pilgrimage-Dhul Hijjah), and in this sacred town (the city of Makkah)." ${ }^{\circ 3}$

Based on this, Islamic scholars have been able to compiled such rights under the distinct body of law known as 'human right law' as a matter of religion and respect to humanity in both peace and war time. This has also implies that human right and humanitarian laws in Islam are not new phenomena. Thus, Al Maududi ${ }^{64}$ while tracing the historical antecedence of the Islamic humanitarian law with a view to affirming its existence

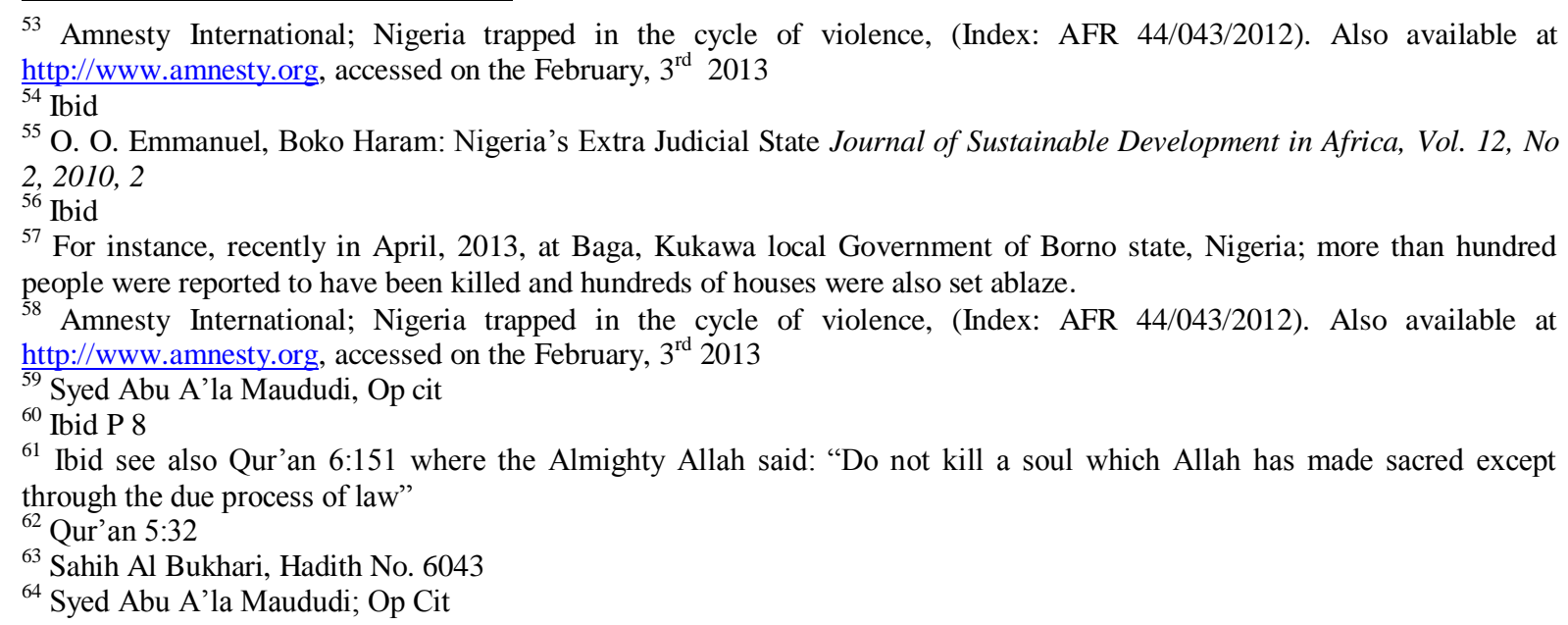


and its application has confirmed that Islamic humanitarian law exists even before the advent of International humanitarian law, and he further said; it predates International humanitarian law which came into being just in the Middle of $19^{\text {th }}$ Century. ${ }^{65}$ Therefore, this position has further affirms that Islam is a religion that bothers not only on the aspects of worship (Ibadat) but also the mundane aspects of human life. Human right in Islam particularly right to life and human dignity are something that could never be taken lightly and sluggishly. To this end, Al Sheha ${ }^{66}$ while making clarifications about some misconceptions on the concept of human right in Islam has confirmed that Islamic law has made preservation of self as an obligation thereby providing a physical security and protection of human life. Thus, Islam has legislated capital and corporal punishments and retribution unto those transgressing criminals who murder and physically harm others. ${ }^{67}$ Similarly, Austin and Colin $^{68}$ have made certain clarifications while reacting to those who considered the concept of human right in Islam as westernization. They said that Islamic human rights and Universal Declaration of Human rights are complementary to each other but not a western project. ${ }^{69}$ In addition, Islamic law has not only provided such protection during peace time but also provided for the protection of civilian persons and object during armed conflicts. To this end, the Almighty Allah said: "And fight in the way of Allah those who fight you, do not transgress (limits). Verily, Allah likes not the transgressors." battalion (army) was also reported to have cautioned them as follows: "Fight in the Name of God, fight those who deny God, kill not children and do not betray, mutilate or commit perfidy" "7l In yet another Hadith, the Prophet (PBUH) prohibited the killing of women, children and priests. He stated that the principle of humanity and virtue should be reported during and after war and to guarantee public and private safety on the battlefield. ${ }^{72}$

According to Karima, ${ }^{73}$ there are absolute humanitarian provisions in the Islamic law of war. Those provisions are based on divine commands and the precepts of the Prophet (PBUH) and constitute inviolable norms; they are not based on reprocity or expedience as thought by some people. ${ }^{74}$ Karima further said: the principles established centuries ago (during the early period of Islam) are equally relevant today. Such principles prohibit terrorizing civilians such as women, children and other non combatants, they are recognized as a separate category of persons entitled to various degrees of immunity from attacks. Indeed, this is a development which may be seen as the birth of the civilian. ${ }^{75}$ Apart from the protection of civilian right to life, she equally said that the civilian property must also be protected. As all wealth is supposed to be trust from God (Allah), therefore, it is considered a serious trespass in Islamic law to destroy it without genuine cause. ${ }^{76}$ Destruction of both life and property has been declared by the Almighty Allah as spreading mischief and corruption on the earth. ${ }^{77}$ In this regard, Al- Qardawi, ${ }^{78}$ commented thus: "the inevitability of war does not at all mean that human should submit to their instincts of anger, cruelty and selfishness. That is to say, if war is unavoidable, let it be controlled by morals, not lust against tyrants and aggressors, not against peaceful persons and innocent." ${ }^{, 79}$ In fact, if it is necessary to fight, it has to be restricted to enemy combatant soldiers and then only in the battle field. This is because of the Prophet's instruction not to cheat, betray the trusted, mutilate, or kill minors,

\footnotetext{
${ }^{65}$ Ibid

66 A. Al Sheha (et al), Human Rights in Islam and Common Misconceptions, available at http/:www.islamhouse.com/d/files/en/ih.../en_Human_Right_in_islam.doc accessed on January, $3^{\text {rd }} 2013$

${ }^{67}$ Ibid P 26 see also the provisions of Qur'an $\overline{2}: 179$ and Qur'an 4: 9

${ }^{68}$ D. Austin, and K. Colin, Islam and Human Rights: Defending Universality at the United Nations (Center for Inquiry international CFI, U.S, 2008) also available at http/:www.centerforinquiry.net, accessed on the June, $10^{\text {th }} 2012$

${ }^{69}$ Ibid

${ }^{70}$ Qur'an 2: 190

71 Muhammad Ibn Isma'il Al Bukhari,: Sahih - Al Bukhari, (Book 4, Volume 52), EBook, available at http://www.imaanstar.com, accessed on the October, $5^{\text {th }}$ 2010. See also H. Sultan, The Islamic Concept', International Dimension of Humanitarian Law (Henry Dunant Institute, Geneva, Martinus Nighoff Publishers, Dordrecht, 1998).37. See also H.Y. Al-mallah, The Governmental System of the Prophet Muhammad (PBUH), A Comparative Study in Constitutional Law (Dar-al Kutub Al Ilmiyya, Beirut-Lebanon (2008/1429 AH) 147, wherein he quoted the Prophet (PBUH) saying: "Fight in the name of God, against those who deny God, and not to steal, betray or disfigure the bodies of the slain and not to kill those who were unable to fight such as children, women and old men."

${ }^{72}$ W. Al- Zuhaili, 'Islam and International law', International Review of the Red Cross, Volume 87, Number 858, 2005, $281-282$

${ }^{73}$ Bennoune, K. Op cit

${ }^{74}$ Ibid

${ }^{75}$ Ibid P 623

${ }^{76}$ Ibid, P. 622

${ }^{77}$ Qur'an 2: 205 where the Almighty Allah said :'When he turns away, his effort in the land is to make mischief therein and to destroy the crops and the cattle, and Allah likes not Mischief."

${ }^{78} \mathrm{Y}$. Al -Qardawi, Introduction to Know Islam (np (1995) 88

${ }^{79} \mathrm{Ibid}$
} 
women, and monks, since they are all regarded as civilians. ${ }^{80}$ Similarly, Sabiq ${ }^{81}$ when commenting on mercy in war had this to say:

Islam had forbidden the killing of women and the children, the sick people, the old people, the friaries, the worshippers and the workers. It has also prohibits mutilation, killing of the animals, spoiling of the plants, destruction of water installations, pollution of wells and destruction of the houses, all for the protection of civilian persons and objects. ${ }^{82}$

Sultan ${ }^{83}$ has equally outlined the general principles of the Islamic humanitarian concepts as regards to protection of civilian population and objects as follows: distinction between civilians and combatants for the purpose of civilian protection; general protection of civilians from indiscriminate attack, dangers of hostilities and military operation; special protection for certain categories of civilians such as children, women, elderly, sick, monks, etc; distinction between civilian object and military objectives; and Principle of precaution and proportionality. ${ }^{84} \mathrm{He}$ further stated that the protection of civilian human rights are enshrined in the Quran (Book of Allah revealed to Prophet Muhammad through the Angel Gabriel [Jibril] for guidance of mankind and Jinn), Sunnah (saying, action and tacit approval) of Prophet Muhammad (PBUH) and other secondary sources of the Islamic law such as Ijma (consensus opinion of scholars) and Qiyas (analogical deduction from the Qur'an and Sunnah by Islamic jurists). ${ }^{85}$ It is also on the basis of Ijma and Qiyas, most of the Arab countries have for the purpose of civilian protection endorsed the ratification of many conventions such as the Geneva Conventions 1949 and their Additional Protocols $1977 .{ }^{47}$ In light of the above, Farah, ${ }^{86}$ took his pains to explain the concept of Jihad in Islam, where he said, "Jihad in a militant context did not affect non Muslim subjects and residents, its affect only combatants who might be militants or rebels." ${ }^{87}$ Thus, Tabassum ${ }^{88}$ has made extensive clarification about the legal status of rebels under Islamic law where she affirms that rebels are recognized as combatants within the purview of Islamic law and therefore giving them a combatant status will reduces a lot of the civilian sufferings during conflicts. ${ }^{89}$ Imam Malik ${ }^{90}$ in his book "Muwatta" reported that Allah prohibits killing of women and children in the battle field as they are purely civilians. ${ }^{91}$ In the words of Bambale, ${ }^{92}$ a great sin as far as the violation of the right of human beings is concerned is, taking human life (Murder). ${ }^{93}$ When Guest, ${ }^{94}$ was discussing the nature of armed conflict in Afghanistan, has laid out some distinctions in relation to the concept of Islamic rules of war, thus, he was able to draw a line of demarcation between the so called Islamic new rules and old rules. According to him, the new rules have placed more restrictions on the means and methods of warfare to be employed than the old one. ${ }^{95}$ In determining the conformity of Afghans code of conduct of the Mujahids with the Islamic jus in bello, Munir ${ }^{96}$ has said that the then Islamic Emirate of Afghanistan established a code of conduct known as "Layha" which contain certain rules that disregard the principle of distinction and as well, allow perfidy (to feigns civilian while launching an attack) which is contrary to the teachings of Islam. ${ }^{97}$ Meanwhile, with respect to Islamic Declaration on Human rights which otherwise known as "Cairo Declaration", 98 it was agreed that human rights and public freedom are integral part of the Islamic belief and

\footnotetext{
80 A.A. An-Na'im, Toward an Islamic Reformation, Civil Liberties, Human Rights and International Law (Syracuse University Press, New York, (1996) 143-149.

${ }^{81}$ S. Sabiq, The Doctrinal writings of the Holy Prophet's Sunnah (Fiqh us-Sunnah (Beirut- Lebanon, Dar al-Islam, 1996) Volume iv, 68

${ }^{82}$ Ibid

${ }^{83}$ H. Sultan, Op Cit, Pp 37-38.

${ }^{84}$ Ibid

${ }^{85}$ Ibid, P 37

${ }^{47}$ ICRC 'Fifth Annual Report on the Implementation of International Humanitarian Law' at the Level of Arab States (2009)

${ }^{86}$ C.E. Farah, Islam Belief and Observances, (Barron's Educational Series, Inc, Woodbury, New York, 1968) 159

${ }^{87}$ Ibid

${ }^{88}$ S. Tabassum, Combatants not bandits: The Status of rebels in Islamic law, International Review of the Red Cross, Vol.93, No.881, March 2011, 121

${ }^{89} \mathrm{Ibid}$

${ }^{90}$ A. Malik, Al Muwatta (The approved)Translated by Gehan Abdel Raouf Hibah, Volume 1, Dar al-Kotob Al Ilmiyyah, Beruit-Lebanon, 2007)

${ }^{91}$ Ibid

${ }^{92}$ Y. Y. Bambale, Crimes and Punishment under Islamic Law (Lagos, Nigeria,Malt house Press Limited, 2003) 89

${ }^{93}$ Ibid

${ }^{94}$ K. Guest, 'Dynamic interplay between Religion and Armed conflict in Afghanistan' International Review of the Red Cross, Volume 92, Number 880, 2010, 887

${ }^{95}$ Ibid

${ }^{96}$ M. Munir, 'The Layha for the Mujahideen: An analysis of the conduct for Taliban Fighters under Islamic law' International Review of the Red Cross, Volume 93, Number 881, 2011, 887

${ }^{97}$ Ibid

${ }^{98}$ Cairo Declaration has came into being on the $5^{\text {th }}$ August, 1990 equivalent to $14^{\text {th }}$ Day of Muharram, $1411 \mathrm{AH}$ 
religion. ${ }^{99}$ Thus, $\mathrm{Al}$ Zuhaili ${ }^{100}$ has laid out the basic rights among other things that are contained in the Cairo Declaration. For instance he said, since all people are children of Adam (Bani Adam), they should be therefore treated equally in terms of human dignity and honour without any discrimination whatsoever on the basis of religion, race, colour, language, sex, political belonging and social status or any other factor. ${ }^{101}$ Similarly, the Declaration has affirmed the existence of the right to life, ${ }^{102}$ right of civilians not to be killed during war, ${ }^{103}$ prohibition of slavery, humiliation and exploitation, ${ }^{104}$ right to life and security in the society relating to his self, religion and faith, family honour, dignity and his financial belongings. ${ }^{105}$ Finally, the Declaration prohibits unlawful detention or restriction or physical or psychological torment or any other humiliating treatment or imposing punishments that are not prescribed by the law (shari'a). ${ }^{106}$ In a similar manner, Kelman, ${ }^{107}$ explained that the crime of torture is considered as a crime of obedience under the Islamic law. This is because; it is performed in response to orders from authority that is considered illegal or immoral by the larger community and it is therefore prohibited by International Declarations and Conventions. ${ }^{108}$

\section{An Analytical Review of the Civilian Rights to Life and Human Dignity under International Law}

Human rights under International law are described as rights that every human being should have by virtue of his or her human dignity. They can also be described as the sum of individual and collective rights laid down in regional and states constitutions. ${ }^{109}$ The rights have covered all aspects of life which comprises civil and political rights, social economic and as well as cultural rights. ${ }^{110}$ Human rights of civilians shall be respected at all times including the period of hostilities. Of course, this is one of the areas where human right law and humanitarian law complement each other. However, that does not mean that the two legal regimes should not conflict with each other. Thus, where there is conflict between the two, then the specific one (humanitarian law) shall prevail. ${ }^{11}$ This is what Lubell ${ }^{112}$ means by the concept of "complementarity" and "Lex specialis". To the effect that, where Human right law conflicts with humanitarian law in the course of application, the special law (lex specialis) which is the humanitarian law in this case, shall prevail. ${ }^{113}$ Even though the application of International humanitarian law itself, sometimes faces some challenges especially with the emergence of the new methods and means of warfare around the globe. According to Afghanistan independent Human Rights Commission, "the armed conflict in Afghanistan has surely affected the civilian population of the country. This was due to the specific practices and cases which were in clear violation of International humanitarian law and other International standards. Thus, such practices and cases include: attacks by armed group, military operations by national and international forces, suicide attacks by anti government elements, air operations and bombing by international forces." 114

According to the Handbook on Parliamentarians, apart from the UN Charter on Human Rights that applies to all states, there are also instruments at the regional level such as the European Convention for the Protection of Human rights and Fundamental freedoms (1950-1953) and its Additional Protocols; American Convention on Human Rights (1969-1978) and its Additional Protocols; African Charter on Human and Peoples' Rights (1981-1986) that applies to their respective regions. ${ }^{115}$ This indicates the importance of human right protection to people in general. Similarly, in the words of Christopher, ${ }^{116}$ Human dignity is also part of the

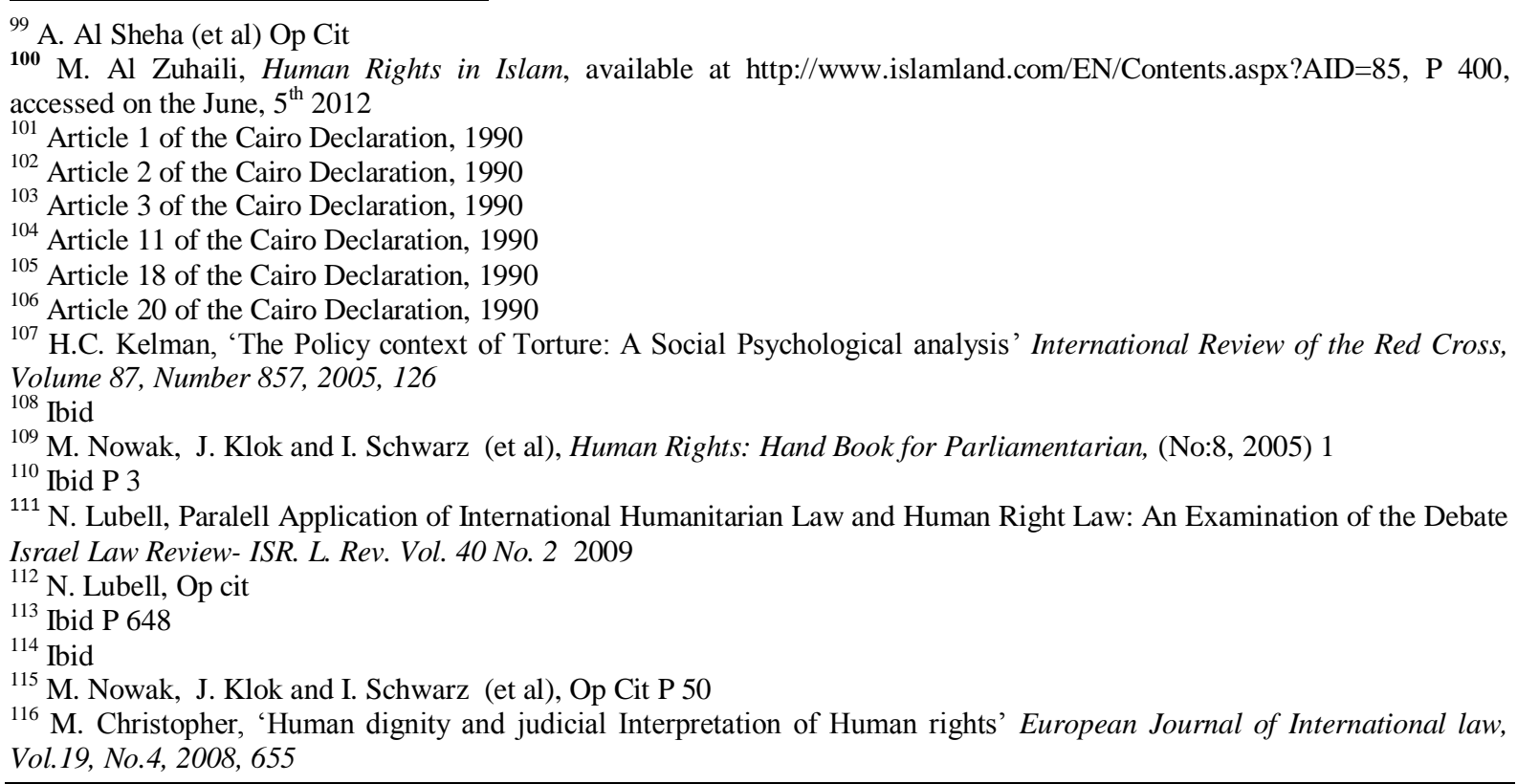


Human rights which historically emanated from the classical Roman term "dignitas hominis" referring to 'status'. ${ }^{117}$ It means honour and respect should be accorded to someone who was worthy and due for that. ${ }^{118}$

Importantly, Solis ${ }^{119}$ while discussing on the conduct of hostilities had this to say: war is distinguishable from murder and massacre only when restrictions are established on the reach of battle. ${ }^{120}$ Bruderlein ${ }^{121}$ also lamented on the protection of civilians in internal armed conflicts, where he affirmed that prevalent threats to civilians and widespread violations of International humanitarian law and human right law by states and non state actors mostly arises in non international armed conflicts. ${ }^{122}$ In fact, such violations according to Borrie and $\mathrm{Brehm}^{123}$ usually occur as a result of using explosive weapons during conduct of hostilities, most especially in populated areas. Yoram ${ }^{124}$ while discussing the effects of suicide attack, explained that, in the recent times, it is turned out to be different phenomenon unlike what was known before in the case of Japanese Kamikaze where combatants undertakes a suicidal mission against legitimate military targets. However, the phenomenon has been used nowadays as a tactic by unlawful combatants in order to launch an attack against civilians and their objects. ${ }^{125}$ According to McCoubrey, ${ }^{126}$ in most of armed conflicts, civilians become the victims by direct effect of hostilities, as a result of injury against their persons and objects ${ }^{127}$ In light of this, Sassoli and Bourvier ${ }^{128}$ have stated that the civilians in most cases are the overwhelming majority of victims of war, thus:

"Increasingly, civilians have become overwhelming majority of victims of armed conflict despite International Humanitarian law stipulate that attacks should only be directed at combatants and military objectives and civilians should be respected. ${ }^{\prime 29}$

On the issue of whose responsibility to protect civilian, the UN has made it an obligation upon all parties to a conflict to protect and respect human life and dignity in all circumstances. To this end, Prommier ${ }^{130}$ has indicated that it is based on the UN principle of "Responsibility to protect" (R2P); states are mandated to protect their citizens within their jurisdiction against any act of genocide, war crime, ethnic cleansing and crimes against humanity ${ }^{131}$ However, if a state fails to do its responsibility, then the International community can take diplomatic or any other means to stop the violence. ${ }^{132}$ However, Gentile ${ }^{133}$ has made clarification between different notions of protection for civilians in armed conflicts or other situation of violence. ${ }^{134}$ Thus he said: the term "protection" could be understood to as: an overall objective (i.e a result to be achieved by all actors: whether humanitarian, political etc); consolidation of a protective legal framework by implementing legal instruments; a concrete activity or self activities: these are usually undertaken by humanitarian actors and it is distinct from legal action (prosecution), political action (e.g sanction and advocacy), military or security action (physical protection). ${ }^{135}$

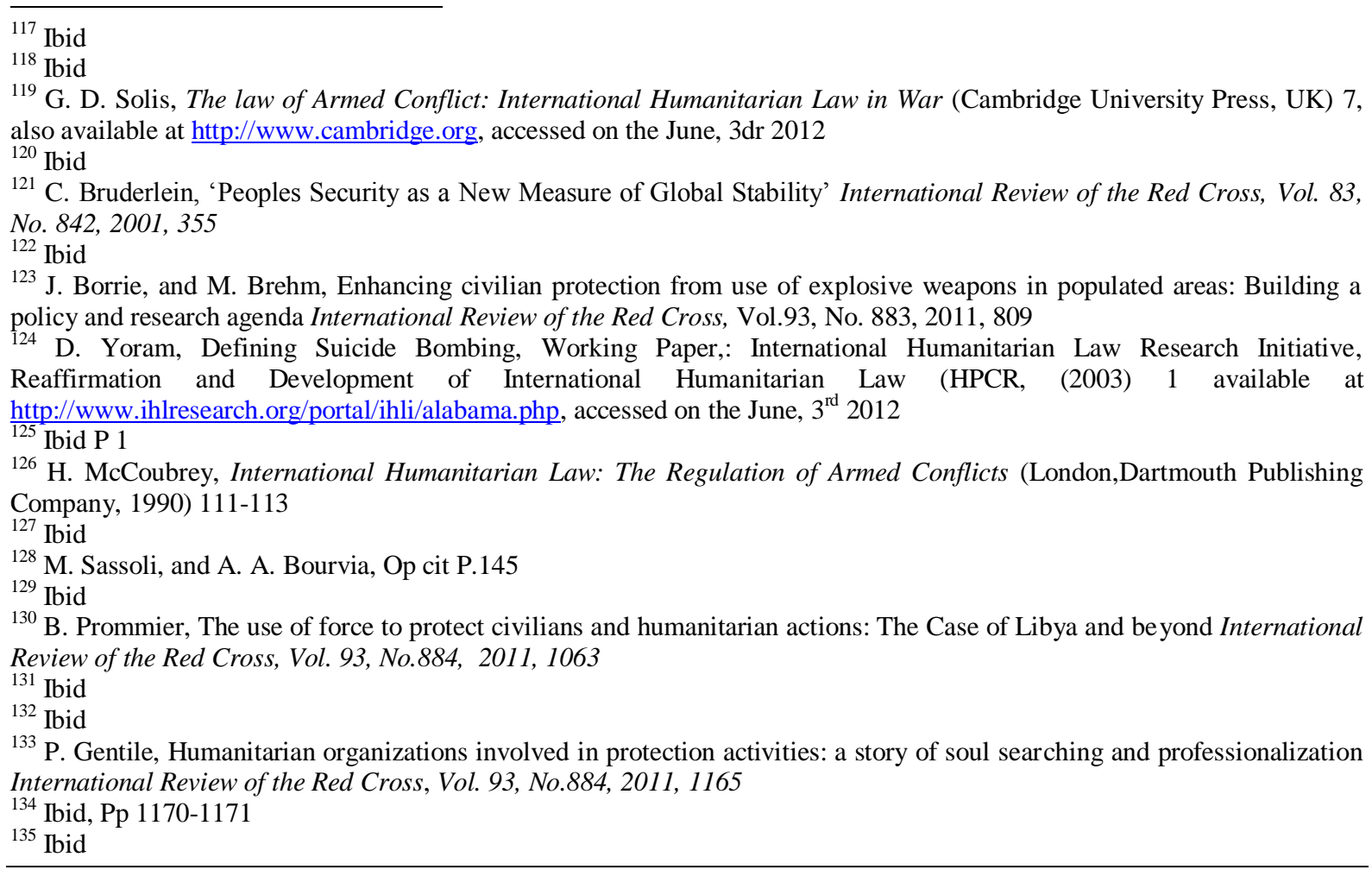


In addition, Wuerzner ${ }^{136}$ has elaborated on the most basic and essential principle for protection of civilian life and human dignity where he cautioned the belligerents to adhere to the principle of distinction. Thus, distinction between civilians and combatants and between civilian objects and military objectives for the purpose of their protection, unless they take part in hostilities as provided for under the Additional Protocol II to the Geneva conventions of 1949 applicable to non International armed conflicts. ${ }^{137} \mathrm{He}$ further said that the protection of civilian life and human dignity may cease entirely or suspended in three exceptional circumstances decided in Kupreski's case, ${ }^{138}$ namely: (i) when civilian abuse their rights (ii) when, although the object of military attack is comprised of military objectives, belligerents cannot avoid causing so-called collateral damage to civilian, and (iii) when civilian may legitimately be the object of reprisals. ${ }^{139}$

The trial Chamber in the Blaskic case ${ }^{140}$ stresses that customary international law which prohibits unlawful attack upon civilian and civilian property whatever the nature of conflict. ${ }^{141}$ Attacks which are not directed at specific military objectives and which employ a method or means of combat that cannot be directed at a specific military objective are indiscriminate and amount to a war crime. ${ }^{142}$ Hence, such attack is prohibited because it is being targeted on civilians and their objects. In ICRC's Publication, ${ }^{143}$ the prohibition of attack on civilians and their property has been reiterated as follows:

"Prohibition of attacks on civilian persons and property includes all acts of violence, whether committed in offence or defence. It also includes attacks launched indiscriminately". ${ }^{144}$

Queguiner ${ }^{145}$ said: respect for civilian persons and objects and protecting them against the effect of hostilities is an important raison d'être of International humanitarian law. ${ }^{146} \mathrm{He}$ then extensively elaborated on the controversies bedevilling the notion and interpretation of the phrase "direct participation of civilian in hostilities" where he pointed out the specific challenges facing such notion as follows: computer network attack and exploitation; so called war on terrorism; and the privatization of armed forces. ${ }^{147}$ Furthermore, he pointed out some legal consequences of the notion as follows: result to loss of immunity from attack; and the legal regime applicable to such civilians in case of capture or detention also raises difficult questions. ${ }^{148}$ The International Committee of the Red Cross (ICRC) recommendations has interpreted the notion of direct participation in hostilities to mean a specific act carried out by individuals as part of the conduct of hostilities between parties to an armed conflict. ${ }^{149}$ However, no mention or interpretation was objectively pointed out as to what that specific act should be. Hence, this has still left a gap within the interpretation.

In the words of Pfanner ${ }^{150}$ International humanitarian law rests on a balance of humanitarian and military interests. In order to prevent the parties sliding into an all-out war ending with the complete destruction of the enemy, their choice of the means and methods of warfare is restricted. ${ }^{151}$ In particular, persons not or no longer taking part in hostilities such as civilians, wounded and captured soldiers must be spared. ${ }^{152}$ In addition, even when a lawful attack is launched, precautionary measures are required of both the attacking party and the party being attacked, in order to avoid (or at least to minimize) the collateral effects of hostilities on civilian

${ }^{136}$ C. Wuerzner, 'Mission Impossible? Bringing Charges for the Crime of attacking Civilians or Civilian Objects before the International Criminal Tribunals', International Review of the Red Cross (Direct participation in Hostilities) Volume 90, Number 872, 2008, 908

${ }^{137} \mathrm{Ibid}$

${ }^{138}$ ICTY, Prosecutor v. Zoran Kupreskic et al (IT-95-16-T), Judgment of 14 January 2000

${ }^{139}$ C. Wuerzner, Op Cit, 916

${ }^{140}$ ICTY, The Prosecutor v. Tihomir Blaskic (IT-95-14), Judgment of 3 March 2000

${ }^{141}$ C. Wuerzner, Op Cit, 908-909

142 J. Henckaerts, and L. Doswald- Beck, Op cit 40

143 ICRC, Understanding Humanitarian Law, Basic Rules of the Geneva Conventions and their Additional Protocols (Geneva, ICRC, 1983-2006).36

${ }^{144}$ Ibid see also Art. 49, 51 and 52 of the Additional P 1 (1977)

${ }^{145}$ J. Queguiner, 'Precaution under the law Governing the Conduct of Hostilities', International Review of the Red Cross, Volume 88, Number 864,2006, 794

${ }^{146} \mathrm{Ibid}$

147 J. Queguiner, Direct Participation in Hostilities under International Humanitarian Law (Working Paper) International Humanitarian Law Research Initiative, Reaffirmation and Development of International Humanitarian Law, HPCR, 20035 available at http://www.ihlresearch.org/portal/ihli/alabama.php, accessed on the $3^{\text {rd }}$ June, 2012

${ }^{148}$ Ibid P 8

149 Abraham, G (2010); 'Direct Participation in Hostilities and the ICRC' s interpretive Guidelines,' in a Paper presentation, presented during the workshop on International Criminal Justice and International Humanitarian Law organized by Abuja, Nigeria, ICRC, 16-18, P.16

${ }^{150}$ T. Pfanner, 'Asymmetrical Warfare from the perspectives of Humanitarian law and Humanitarian Action', International Review of the Red Cross, Volume 87, Number 857, 2005, 160-161

${ }_{151}^{1}$ Ibid

${ }^{152}$ Ibid 
persons, the civilian population and civilian objects. ${ }^{153}$ All precautions must be taken to avoid loss of civilian life, injury to civilians and damage to civilian objects. That is to say, each party to the conflict must do everything possible to avoid civilian casualties. Therefore, launching an attack which may be expected to cause incidental loss to civilian life, injury to civilians, damage to civilian objects, or a combination thereof, is prohibited. In fact, attacks shall only be directed against combatants and military objects but not against civilian and civilian objects unless and for such time the civilians take a direct part in hostilities or a civilian object become military objectives. ${ }^{154}$ Furthermore, according to Bourvier, ${ }^{155}$ respect for human dignity does not stop only for a living person. Thus, it requires respect for the dead even. ${ }^{156}$

Umozurike ${ }^{157}$ has described humanitarian law and human rights law as two sides of a coin that derives from the basic principles that individual is entitled to certain minimum rights in peace or in war. Thus, the former applies during war while the latter applies at all times. ${ }^{158}$ There are materials regulating armed conflict under International humanitarian law, to this end, Sandesh ${ }^{159}$ highlighted that apart from the Geneva Conventions 1949 and their Additional Protocols 1977, there are other materials regulating non International armed conflicts of which some emanates from various states codes and others from armed groups. However, such materials usually been made as reference to International humanitarian law or human rights law. ${ }^{160}$

\section{Conclusion}

Generally, Islamic and International laws have laid out the provisions for the protection of people's lives and human dignity both during war and peace time. Specifically, the civilian lives and human dignity could be safeguarded during conflicts provided that they do not participate in the hostilities. However, the two legal regimes (Islamic and International laws) differ as to the actual interpretation of "civilian participation" in hostilities. Thus, majority of jurists in Islamic law recognizes both direct and indirect participation of civilian as a ground for the forfeiture of the civilian status, whereas under the International law, civilian can only forfeit his status if he or she has directly or actively participated in the hostilities. What constitute "indirect participation" under Islamic law and as well as the "active participation" under International law as the case may be still remain a controversial phenomenon. Furthermore, unlike the International laws which some of its branches applies in peace time and some in war time, Islamic law does not have that demarcation when it comes to the issues for the application of human rights (i.e. it applies at any time and place). Similarly, looking at the situation in Northern Nigeria concerning the violation of civilian rights to life and human dignity, it seems that the issues are inadequately addressed by the existing applicable law (human right law). In view of this therefore, the paper suggests the following:

(i) Adequate application of the appropriate law that can fit a peculiar situation (fitness for purpose). That is to say, the UN should adopt another Protocol in addition to the existing ones that can extend the scope for the application of humanitarian law to cover other situations of violence other than armed conflicts.

(ii) The United Nations (UN) should adopt an Additional Protocol in order to recognize the application of Islamic human right and humanitarian laws in advanced to the establishment of the regional Islamic courts of human rights within the Muslim dominated states.

(iii) The Islamic Muftis ( jurist-consults) in collaboration with the UN and OIC should come out with a tentative, harmonized and definite meaning of "civilian participation" in hostilities so that the actual civilians could easily be distinguished from combatants.

\section{References}

[1]. N. Badawi, Introduction to Islamic law, Programme on Humanitarian Policy and Conflict Research (USA, Harvard University, 2009)

[2]. M. Kyari, 'Application of Shari'a in Borno under the Colonial Rule, (1902-1960),' in M. A. Muazu et al (eds), Perspective in Sharia (Maiduguri, Nigeria, Sakirabe Publishers 2002)

A. I. Doi, Shari'a the Islamic Law (London, TA HA Publishers, 1984)

[3]. Saheen, S. A and Javaid, R (2005); 'The concept of Jihad in Islamic International Law,' Volume 10, No.3, Journal of Conflict and Security Law,

[4]. M. Khadduri, The Islamic Law of Nations: Shaybani's Siyar (1966)

\footnotetext{
${ }^{153}$ Queguiner, J., Op Cit, P 794

${ }^{154}$ Henckaerts, J. And Doswald- Beck, L., Op Cit Pp 198-202

${ }^{155}$ P. Bourvier, "Yo lo Vi" Goya witnessing the disasters of war: an appeal to the sentiment of Humanity, International Review of the Red Cross, Vol. 93, No.884, 2011, 1107

${ }^{156} \mathrm{Ibid}$

${ }^{157}$ U.O. Umozurike, Introduction to International Law (Ibadan, Nigeria, Spectrum Books Limited, 2005) 212

${ }^{158}$ Ibid

${ }^{159} \mathrm{~S}$. Sandesh, 'Lessons for the Law of Armed Conflict from commitments of armed groups: Identification of Legitimate Targets and Prisoners of War' International Review of the Red Cross Vol. 93, No. 882,2011, 1

${ }^{160}$ Ibid P 2
} 
[5]. M. Hamidullah, Muslim Conduct of State: Being a Treaties on Siyar, that is Islamic Notion of Public International Laws of Peace, War and Neutrality, Together with Precedents from Orthodox practices and Precedent by a Historical and General Introduction, (1977)

[6]. M. T. Al Ghunaimi, The Muslim conception of International law and the western approach, (The Hague, Martinus, Nijjhoff, 1968)

[7]. S.T. Troy, Jihad's Captives: Prisoners of war in Islam (Report of the Department of Defence, Washington DC, 20301, 2005)

[8]. U.O. Umozurike, Introduction to International law (Ibadan, Nigeria, Spectrum Books Limited, 2005)

[9]. I.J. Mohammed Naqib, Principles of Public International Law A Modern Approach (Malaysia, IIUM Press, 2011)

[10]. S.A. Williams, \& ALC de Mestral, An Introduction to International law (Toranto, Butterworth, $2^{\text {nd }}$ ed, 1987)

[11]. M. M. Mahboub, War and the Protection of Rights of Individuals: An Examination of Islamic and International Humanitarian Laws (Triumph Publishing Company, (nd)

[12]. K. Bennoune, 'Assalamu Alaikum? Humanitarian Law in Islamic Jurisprudence,' (Vol. 15, No.2) Michigan Journal of International Law (MICH. J. INT' L.)

[13]. N. Badawi, Islamic Jurisprudence and the Regulation of Armed Conflict, Programme on Humanitarian Policy and Conflict Research,_ (USA, Harvard University, 2009) available http://ihl.ihlresearch.org/_data/global/images/Islamic_Jurisprudence_Regulation_AC.pdf (accessed on the November, 26 ${ }^{\text {th }}$ 2010)

[14]. ICRC, Basic Rules of the Geneva Conventions and their Additional Protocols, (Geneva, ICRC, 2006).

[15]. Available at http://www.answers.com/topic/civilian, accessed on the November, $1^{\text {st }} 2010$

[16]. M. Sassoli, and A. A. Bourvia, How Does Law Protects in War (Cases Documents and Teaching Materials on Contemporary Practice), International Humanitarian Law (Geneva, ICRC, 1999)

[17]. L. Doswald-Beck (et al), International Humanitarian Law, An Anthology (Lexis Nexis- Butterworhs Wadhwa, India 2009)

[18]. ICRC, Hand Book on the Law of War for Armed Forces (ICRC, Geneva, 1999)

[19]. ICRC, 'Interpretative Guidance on the Notion of Direct Participation in Hostilities under the International Humanitarian Law,' ICRC, (2009)

[20]. M. Nowak, J. Klok and I. Schwarz (et al), Human Rights: Hand Book for Parliamentarian, No:8, 2005)

[21]. The Constitution of the Federal Republic of Nigeria 1999 (as amended)

[22]. Syed Abu A'la Maududi, Human Rights in Islam, (13-E Shah Alam Market, Lahore, Pakistan Islamic Publication Limited)

[23]. M. H. Kamali, Human dignity in Islam (Malaysia, International Institute of Advanced Islamic studies IAIS, 2008)1

[24]. M. Christopher, 'Human dignity and judicial Interpretation of Human rights,' European Journal of International law, Vol.19, No.4

[25]. O. Bamidele, 'Boko Haram Catastrophic Terrorism- An Albatros to National Peace Security and Sustainable Development in Nigeria' Journal of Sustainable Development in Africa, Vol. 14, No. 1

[26]. US report available at http://elombah.com/us/report, accessed on the July, $15^{\text {th }} 2012$

O. Oransanye, and A. A. Igbafe, An Assessment of the Terrain of Conflicts, Violence and Crimes, African Journal of Social Sciences, Vol. 2, No 12012

[27]. Amnesty International; Nigeria trapped in the cycle of violence, (Index: AFR 44/043/2012). Also available at http://www.amnesty.org, accessed on the February, $3^{\text {rd }} 2013$

[28]. O. O. Emmanuel, Boko Haram: Nigeria’s Extra Judicial State Journal of Sustainable Development in Africa, Vol. 12, No 2, 2010

[29]. Amnesty International; Nigeria trapped in the cycle of violence, (Index: AFR 44/043/2012). Also available at http://www.amnesty.org, accessed on the February, $3^{\text {rd }} 2013$

[30]. Sahih Al Bukhari, Hadith No. 6043

A. Al Sheha (et al), Human Rights in Islam and Common Misconceptions, available at $\mathrm{http} / \mathrm{www}$. islamhouse.com/d/files/en/ih.../en_Human_Right_in_islam.doc accessed on January, $3^{\text {rd }} 2013$

[31]. D. Austin, and K. Colin, Islam and Human Rights: $\bar{D}$ efending Universality at the United Nations (Center for Inquiry international CFI, U.S, 2008) also available at http/:www.centerforinquiry.net, accessed on the June, $10^{\text {th }} 2012$

[32]. Muhammad Ibn Isma'il Al Bukhari,: Sahih - Al Bukhari, (Book 4, Volume 52), EBook, available at http://www.imaanstar.com, accessed on the October, $5^{\text {th }}$ 2010. See also H. Sultan, The Islamic Concept', International Dimension of Humanitarian Law (Henry Dunant Institute, Geneva, Martinus Nighoff Publishers, Dordrecht, 1998)

[33]. H.Y. Al-mallah, The Governmental System of the Prophet Muhammad (PBUH), A Comparative Study in Constitutional Law (Dar-al Kutub Al Ilmiyya, Beirut-Lebanon (2008/1429 AH)

[34]. W. Al- Zuhaili, 'Islam and International law', International Review of the Red Cross, Volume 87, Number 858, 2005

[35]. Y. Al-Qardawi, Introduction to Know Islam (np (1995)

[36]. A.A. An-Na'im, Toward an Islamic Reformation, Civil Liberties, Human Rights and International Law (Syracuse University Press, New York, (1996)

[37]. S. Sabiq, The Doctrinal writings of the Holy Prophet's Sunnah (Fiqh us-Sunnah (Beirut- Lebanon, Dar al-Islam, 1996) Volume iv

[38]. ICRC 'Fifth Annual Report on the Implementation of International Humanitarian Law' at the Level of Arab States (2009)

[39]. C.E. Farah, Islam Belief and Observances, (Barron's Educational Series, Inc, Woodbury, New York, 1968)

[40]. S. Tabassum, Combatants not bandits: The Status of rebels in Islamic law, International Review of the Red Cross, Vol.93, No.881, March 2011

Malik, Al Muwatta (The approved)Translated by Gehan Abdel Raouf Hibah, Volume 1, Dar al-Kotob Al Ilmiyyah, Beruit-Lebanon, 2007)

[41]. Y. Y. Bambale, Crimes and Punishment under Islamic Law (Lagos, Nigeria,Malt house Press Limited, 2003)

[42]. ' ${ }^{1}$ K. Guest, 'Dynamic interplay between Religion and Armed conflict in Afghanistan' International Review of the Red Cross, Volume 92, Number 880,2010

[43]. M. Munir, 'The Layha for the Mujahideen: An analysis of the conduct for Taliban Fighters under Islamic law' International Review of the Red Cross, Volume 93, Number 881, 2011

[44]. Cairo Declaration has came into being on the $5^{\text {th }}$ August, 1990 equivalent to $14^{\text {th }}$ Day of Muharram, $1411 \mathrm{AH}$

[45]. M. Al Zuhaili, Human Rights in Islam, available at http://www.islamland.com/EN/Contents.aspx?AID=85, accessed on the June, $5^{\text {th }}$ 2012

[46]. H.C. Kelman, 'The Policy context of Torture: A Social Psychological analysis' International Review of the Red Cross, Volume 87, Number 857, 2005

[47]. M. Nowak, J. Klok and I. Schwarz (et al), Human Rights: Hand Book for Parliamentarian, (No:8, 2005)

[48]. N. Lubell, Paralell Application of International Humanitarian Law and Human Right Law: An Examination of the Debate Israel Law Review-ISR. L. Rev. Vol. 40 No. 22009

[49]. M. Christopher, 'Human dignity and judicial Interpretation of Human rights' European Journal of International law, Vol.19, No.4, 2008 
[50]. G. D. Solis, The law of Armed Conflict: International Humanitarian Law in War (Cambridge University Press, UK) also available at http://www.cambridge.org, accessed on the June, $3 \mathrm{dr} 2012$

[51]. C. Bruderlein, 'Peoples Security as a New Measure of Global Stability' International Review of the Red Cross, Vol. 83, No. 842, 2001

[52]. J. Borrie, and M. Brehm, Enhancing civilian protection from use of explosive weapons in populated areas: Building a policy and research agenda International Review of the Red Cross, Vol.93, No. 883, 2011

[53]. D. Yoram, Defining Suicide Bombing, Working Paper,: International Humanitarian Law Research Initiative, Reaffirmation and Development of International Humanitarian Law (HPCR, (2003) 1 available at http://www.ihlresearch.org/portal/ihli/alabama.php, accessed on the June, $3^{\text {rd }} 2012$

[54]. H. McCoubrey, International Humanitarian Law: The Regulation of Armed Conflicts (London,Dartmouth Publishing Company, 1990)

[55]. B. Prommier, The use of force to protect civilians and humanitarian actions: The Case of Libya and beyond International Review of the Red Cross, Vol. 93, No.884, 2011

[56]. P. Gentile, Humanitarian organizations involved in protection activities: a story of soul searching and professionalization International Review of the Red Cross, Vol. 93, No.884, 2011

[57]. C. Wuerzner, 'Mission Impossible? Bringing Charges for the Crime of attacking Civilians or Civilian Objects before the International Criminal Tribunals', International Review of the Red Cross (Direct participation in Hostilities) Volume 90, Number 872, 2008

[58]. ICTY, Prosecutor v. Zoran Kupreskic et al (IT-95-16-T), Judgment of 14 January 2000

[59]. ICTY, The Prosecutor v. Tihomir Blaskic (IT-95-14), Judgment of 3 March 2000

[60]. ICRC, Understanding Humanitarian Law, Basic Rules of the Geneva Conventions and their Additional Protocols (Geneva, ICRC, 1983-2006)

[61]. J. Queguiner, 'Precaution under the law Governing the Conduct of Hostilities', International Review of the Red Cross, Volume 88, Number 864,2006

[62]. J. Queguiner, Direct Participation in Hostilities under International Humanitarian Law (Working Paper) International Humanitarian Law Research Initiative, Reaffirmation and Development of International Humanitarian Law, HPCR, 20035 available at http://www.ihlresearch.org/portal/ihli/alabama.php, accessed on the $3^{\text {rd }}$ June, 2012

[63]. Abraham, G (2010); 'Direct Participation in Hostilities and the ICRC's interpretive Guidelines,' in a Paper presentation, presented during the workshop on International Criminal Justice and International Humanitarian Law organized by Abuja, Nigeria, ICRC

[64]. T. Pfanner, 'Asymmetrical Warfare from the perspectives of Humanitarian law and Humanitarian Action', International Review of the Red Cross, Volume 87, Number 857, 2005

[65]. P. Bourvier, "Yo lo Vi" Goya witnessing the disasters of war: an appeal to the sentiment of Humanity, International Review of the Red Cross, Vol. 93, No.884, 2011

[66]. U.O. Umozurike, Introduction to International Law (Ibadan, Nigeria, Spectrum Books Limited, 2005)

[67]. S. Sandesh, 'Lessons for the Law of Armed Conflict from commitments of armed groups: Identification of Legitimate Targets and Prisoners of War' International Review of the Red Cross Vol. 93, No. 882,2011 